\title{
Performance analysis of a Copper Indium Gallium Selenide (CIGS) based Photovoltaic Thermal (PV/T) water collector
}

\author{
Afzam Zulkepli ${ }^{1}$, MRR Chand ${ }^{1}$, Thamir K Ibrahim $^{1}$, Hamzah Sakidin ${ }^{2}$ and Firdaus \\ Basrawi1 1,*, Mohd Hazwan Yusof ${ }^{1}$ \\ ${ }^{1}$ Energy Sustainability Focus Group, Faculty of Mechanical Engineering, Universiti Malaysia Pahang, \\ Pekan, Pahang, Malaysia. \\ ${ }^{2}$ Faculty of Mechanical Engineering, Universiti Teknologi Petronas, 32610, Tronoh, Perak, Malaysia.
}

\begin{abstract}
This paper intended to investigate the performance of Copper Indium Gallium Selenide (CIGS) based Photovoltaic Thermal (PV/T) water collector under different operating condition. A CIGS photovoltaic with nominal power $65 \mathrm{~W}$ combined with an unglazed flat plate solar thermal water collector with effective area of $2 \mathrm{~m}$ was investigated. The performance was tested under different mass flow rates of flowing water which are 0.005 $\mathrm{kg} / \mathrm{s}, 0.020 \mathrm{~kg} / \mathrm{s}$ and $0.030 \mathrm{~kg} / \mathrm{s}$. For the mass flow rate of $0.030 \mathrm{~kg} / \mathrm{s}$, data was taken at different Peak Sun Hour (PSH) condition from 4.2 to 5.7. It was found that both electrical and thermal efficiency increased when the mass flow rate increased. Both electrical and thermal performance increased at the higher mass flow rate with the most efficient flow rate was $0.030 \mathrm{~kg} / \mathrm{s}$. The highest electrical and thermal efficiency was $4 \%$ and $23 \%$ respectively. In addition, when PSH increased, the electrical and thermal efficiency increased. However, at the PSH of 5.7 both efficiency slightly decreased. Further study on higher mass flow rate is necessary as the performance is not always proportional with mass flow rate. In this paper the value of the PSH was only limited to 4 points, which need to be further investigated for more values to clarify the correlation with the PV/T performance.
\end{abstract}

\section{Introduction}

Growing concern towards environmental crisis on worsening nowadays has increased the interest in solar based energy research. Photovoltaic thermal (PV/T) emerged as one of the promising system. PV/T combines two systems which are conventionally operate separately. Photovoltaic system and solar thermal collector system are combined to generate heat and electricity simultaneously [1]. Photovoltaic is however only convert small fraction of solar energy into electricity, where the rest of the energy are wasted into heat energy and increase the photovoltaic temperature. The electrical performance of photovoltaic degrades when the temperature of solar cell increases. By combining photovoltaic with the solar thermal collector, the temperature of Photovoltaic can be reduced by means of the flowing medium

*Corresponding author: mfirdausb@ump.edu.my 
in the solar thermal collector. Furthermore, the wasted heat energy can be absorbed and utilized [2].

$\mathrm{PV} / \mathrm{T}$ can be distinguished by the type of the flowing medium in the solar thermal collector. Most commonly used are water and air. Water based PV/T has more applications compared with air based [3]. Besides that, several studies apply refrigerant as the medium. $\mathrm{PV} / \mathrm{T}$ can be a flat plate or concentrating collector. PV/T concentrating collector is used to increase the intensity of solar irradiance on PV module [4]. For the flat plate PV/T it can be further classified into the absorber design and configuration. The absorber shape of the solar collector can be round tube or square/rectangular tube. Ibrahim et.al [5] investigated the effect of different absorber design such as oscillatory, direct flow, modified serpentineparallel flow, spiral flow, parallel-serpentine flow and web flow. The best result showed by spiral flow design with $68 \%$ thermal efficiency. PV/T also can be glazed or unglazed. Tiwari and Soda [6] carried out a study to compare the performance of glazed and unglazed PV/T. The glazed without tedlar showed the highest efficiency. Partially covered and fully covered PV/T has been studied by Dubey and Tiwari [7] using mathematical modelling. The fully covered PV/T increase the thermal efficiency but decrease the electrical efficiency and beneficial if the primary load is thermal. Partially covered PV/T is more beneficial if the primary load is electricity. Chow [8] introduced an explicit dynamic model to study the performance of single-glazed sheet-and-tube collector. Performance of separately photovoltaic and solar collector and PV/T has been compared by Zondag et.al [9]. PV/T is found to be more efficient than separately installed PV and solar collector.

The performance of PV/T is influenced by several parameters. The performance of PV/T can be effected by the packing factor of the system. As stated by Vats et.al [13], the increase of packing factor is not always proportional with the system efficiency. An optimal packing factor value is crucial because higher packing factor value will increase the temperature of PV module while low packing factor value will reduce the solar radiation absorber area. The electrical efficiency of PV/T system is strongly related with the type of photovoltaic used. The first generation of PV are amorphous silicon, single crystalline and polycrystalline which produced by silicon semi-conductor [14]. Then, the second generation of PV was invented to improve the flexibility and manufacturing cost. On the other hand, mass flow rate of the flowing medium plays an important role in absorbing heat from PV module. The flowing medium can be a thermosyphon system which is naturally moved [10] or by force using a pump [11]. In previous studies, effect of mass flow rate has been investigated in the range of $0.01 \mathrm{~kg} / \mathrm{s}-0.30 \mathrm{~kg} / \mathrm{s}$ [12]. A study on unglazed PV/T for different mass flow rate has been carried out by Zulkepli et.al [13] and it was reported that the highest thermal efficiency achieved at the mass flow rate of $0.12 \mathrm{~kg} / \mathrm{s}$.

CIGS thin film is one of the second generation of PVs and it is thin and very light weight [14]. However, CIGS based PV/T system is still not comprehensively studied. Therefore, this paper intended to investigate the performance of CIGS based PV/T under different mass flow rates. Three different mass flow rates were investigated which are $0.005 \mathrm{~kg} / \mathrm{s}, 0.020 \mathrm{~kg} / \mathrm{s}$ and $0.030 \mathrm{~kg} / \mathrm{s}$. Furthermore, for the mass flow rate of $0.030 \mathrm{~kg} / \mathrm{s}$, data was taken for different value of PSH day. The correlation of mass flow rate and PSH value with the PV/T performance was finally studied. 


\section{Methodology}

\subsection{Experimental setup}

The experiment was conducted during the period from Jun to July 2016 at Pekan, Pahang with altitude of $3^{\circ} 32^{\prime} 07.8^{\prime \prime} \mathrm{N} 103^{\circ} 25^{\prime} 51.3^{\prime \prime} \mathrm{E}$. The specifications of the system are listed in Table 1.

Table 1. System specification.

\begin{tabular}{|c|c|c|}
\hline \multirow[t]{6}{*}{ CIGS } & Rated Power, Pmax & 65 \\
\hline & Voltage at Maximum Power, Vmpp[V] & 15.3 \\
\hline & Current at Maximum Power, Impp[A] & 4.26 \\
\hline & Open Circuit Voltage, Voc[V] & 22.2 \\
\hline & Short Circuit Current, Isc[A] & 5.4 \\
\hline & Effective Area, $\mathrm{A}\left[\mathrm{m}^{2}\right]$ & 0.96 \\
\hline \multirow{2}{*}{$\begin{array}{l}\text { Thermal } \\
\text { Collector }\end{array}$} & \multicolumn{2}{|l|}{ Unglazed flat plate collector } \\
\hline & Area, $\mathrm{A}\left[\mathrm{m}^{2}\right]$ & 2.0 \\
\hline $\begin{array}{l}\text { Storage } \\
\text { tank }\end{array}$ & Capacity [L] & 180 \\
\hline
\end{tabular}

A CIGS solar was combined with a flat-plate solar thermal collector that was connected to a water storage tank to store the thermal energy. For the electrical storage, the photovoltaic was connected to a charge controller and a series of $12 \mathrm{~V}$ lead acid battery. Figure 1 shows the diagram of the system. Photovoltaic was connected to a data logger to measure the power output using voltage sensor and current sensor. A $12 \mathrm{~V}$ bulb was used as the load to discharge the battery. Thermocouples type $\mathrm{K}$ were used to measure the temperature of inlet, outlet, water in storage tank, and solar cell temperature. A $10 \mathrm{~W}$ water pump combined with a ball valve were used to flow and regulate the water flow rate. Flow sensor was installed in the piping system to measure the flow rate of the water. For the solar irradiance measurement, a pyranometer (Kipp \& Zonen CM3) was installed nearby the setup experiment. For this study, 3 different mass flow rates which were $0.005 \mathrm{~kg} / \mathrm{s}, 0.020 \mathrm{~kg} / \mathrm{s}$ and $0.030 \mathrm{~kg} / \mathrm{s}$ were regulated to investigate the optimal flow rate. Furthermore, the experiment was also conducted during different PSH value for the flow rate of $0.030 \mathrm{~kg} / \mathrm{s}$ to investigate the correlation of PSH and $\mathrm{PV} / \mathrm{T}$ performance.

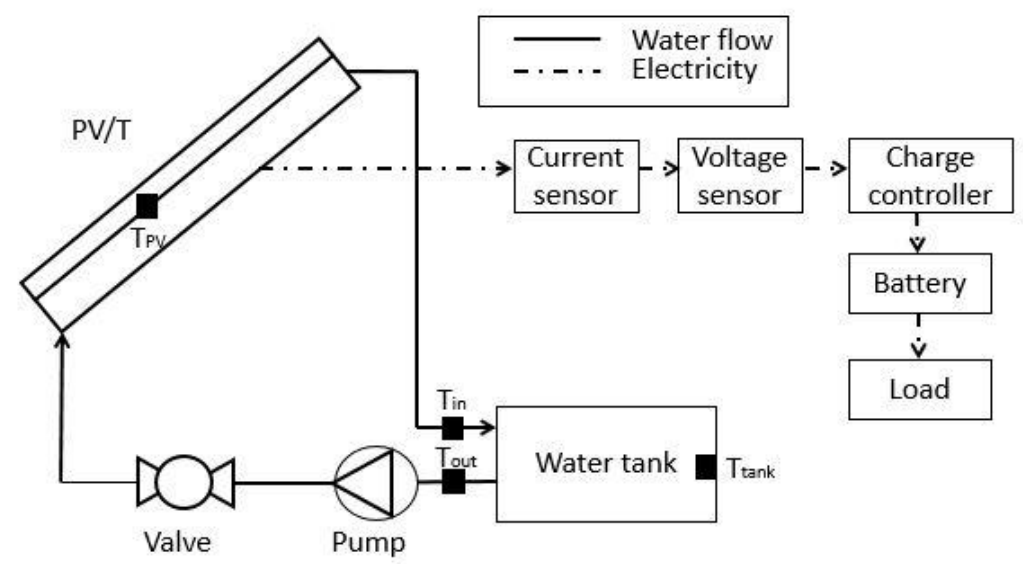

Fig. 1. Schematic diagram of experiment. 
For the uncertainty analysis, all the uncertainty of measured parameters are listed in Table 2 .

Table 2. Uncertainty for measured parameters.

\begin{tabular}{|l|c|c|}
\hline Parameter & Unit & Uncertainty \\
\hline ambient temperature & ${ }^{\circ} \mathrm{C}$ & \pm 0.05 \\
\hline inlet water temperature & ${ }^{\circ} \mathrm{C}$ & \pm 0.05 \\
\hline outlet water temperature & ${ }^{\circ} \mathrm{C}$ & \pm 0.05 \\
\hline solar cell temperature & ${ }^{\circ} \mathrm{C}$ & \pm 0.05 \\
\hline mass flow rate & $\mathrm{kg} / \mathrm{s}$ & \pm 0.005 \\
\hline solar iradiation intensity & $\mathrm{W} / \mathrm{m}^{2}$ & \pm 5 \\
\hline voltage & $\mathrm{V}$ & \pm 0.005 \\
\hline current & $\mathrm{A}$ & \pm 0.005 \\
\hline electrical efficiency & $\%$ & \pm 5 \\
\hline thermal efficiency & $\%$ & \pm 5 \\
\hline
\end{tabular}

\subsection{PV/T performance analysis}

The overall efficiency of PV/T $\eta_{\text {total }}$ was used to evaluate the performance of the system:

$$
\eta_{\text {total }}=\eta_{e l}+\eta_{t h}
$$

The electrical efficiency $\eta_{e l}$ is the function of the output of photovoltaic and solar irradiance which can be calculated by the following equation:

$$
\eta_{e l}=\frac{I V}{G \cdot A}
$$

where $\mathrm{I}$ is the output current, $\mathrm{V}$ is the output voltage, $\mathrm{G}$ is the solar irradiance on the module, and $\mathrm{A}$ is the area of the photovoltaic. Thermal efficiency can be calculated by dividing useful heat gain of inlet and outlet with incident solar irradiation;

$$
\eta_{\text {th }}=\frac{\dot{m} C_{P}\left(T_{\text {out }}-T_{\text {in }}\right)}{G \cdot A}
$$

where $m$ is the mass flow rate of water, $C_{p}$ is the water specific heat, $T_{\text {out }}$ is the outlet temperature and $T_{\text {in }}$ is the inlet temperature. To reduce the effect of fluctuation of the ambient temperature and solar radiation Hottel-Willier model was introduced:

$$
Q_{u}=A_{C}\left[G F_{R}(\tau \alpha)_{e}-F_{R} U_{L}\left(T_{i n}-T_{a}\right)\right]
$$

The thermal efficiency as a function of reduced temperature can be defined by:

$$
\eta_{t h}=F_{R}(\tau \alpha)_{e}-F_{R} U_{L} \frac{T_{i n}-T_{a}}{G}
$$

where $F R$ is the collector efficiency at zero reduced temperature and $F R U L$ is the heat loss of collector. Thermal efficiency of collector obtained from experiment is plotted into y axis, while (Tin-Ta)/Gis plotted into axis. The slop of the linear function represents the $F_{R} U_{L}$ and the intercept with y axis represent the $F_{R}$. In order to validate the output power of 
photovoltaic, the experimental results were compared with simulated results which is a function of solar irradiation and solar cell temperature as shown in equation 6 .

$$
P_{P V}(t)=P_{\max } K_{G} K_{T}
$$

where $K_{G}$ is the coefficient of solar irradiation while $K_{T}$ is the coefficient of operating temperature. $K_{G}$ is the ratio of measured solar irradiance to the solar irradiance at STC.

$$
K_{G}(t)=\frac{G_{T}(t)}{G_{S T C}}
$$

While $K_{T}$ was measured by using the following equation;

$$
K_{T}=\left[1+\left(\frac{\beta}{100}\right) \times\left(T_{C}(t)-T_{\text {STC }}\right)\right]
$$

where $\beta$ is the temperature coefficient of solar cell, $T_{C}(t)$ is measured solar cell temperature, and $T_{S T C}$ is solar cell temperature at STC.

\section{Result and Discussion}

Figure 2 shows a daily electrical performance test of photovoltaic taken from 9.00 a.m until 5:00 p.m for the flow rate $0.005 \mathrm{~kg} / \mathrm{s}$ with PSH value 5.5. The curve shows the output power of the photovoltaic are in a good agreement with the solar irradiation. The outputs fluctuated during the noon time because of cloudy condition. It was also found that the solar irradiance can exceed above $900 \mathrm{~W}$.

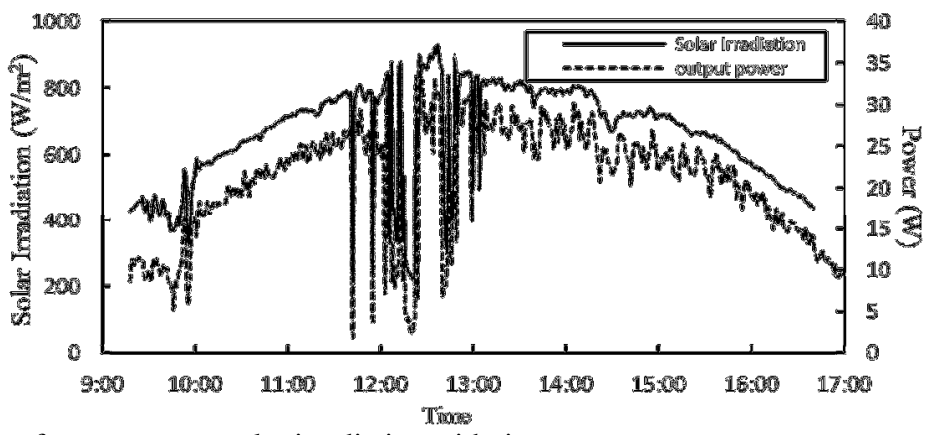

Fig. 2. Variation of power output solar irradiation with time.

The experimental result was then compared to the simulated result which is the function of solar irradiation and solar cell temperature as shown in Figure 3. The difference between the two results was observed to be huge during morning and evening. This is because the simulation model was only limited to the function of solar irradiation and solar cell temperature. There are other parameters that can affect the output voltage and current such as dust effect and mismatch effect. During the noon the results show a good agreement with difference below $5 \%$. 


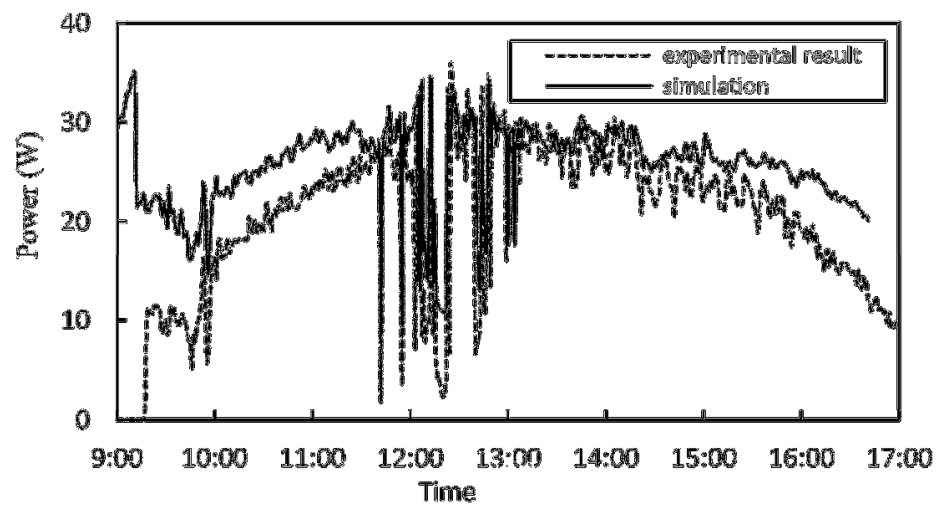

Fig. 3. Comparison of experimental result and simulation.

For the thermal efficiency at zero reduced temperature, the thermal efficiency is plotted against $\left(T_{i n}-T_{a}\right) / G$. Figure 4 shows the plot of thermal efficiency for flow rate of $0.005 \mathrm{~kg} / \mathrm{s}$. It was found that the linear regression line intercept the $y$ axis at the point 0.147 which defines the collector efficiency at $0.005 \mathrm{~kg} / \mathrm{s}$ mass flow rate is $14.7 \%$.

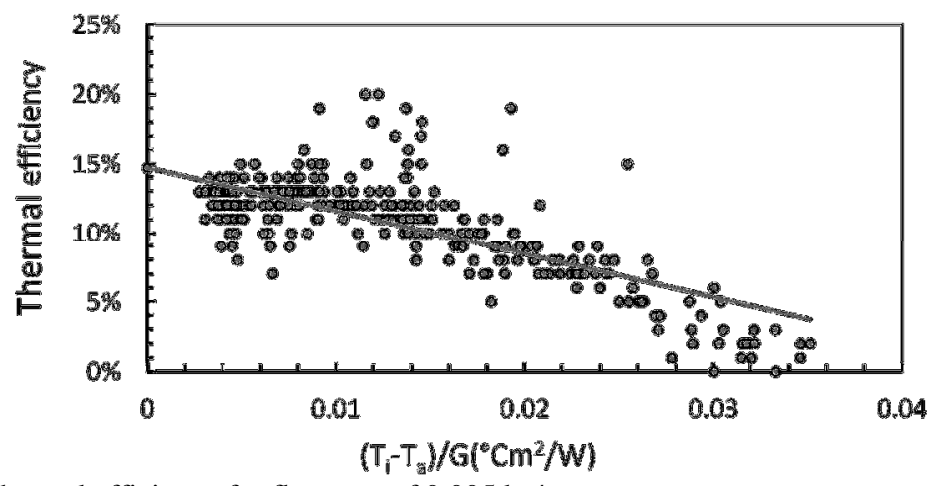

Fig. 4. Plot of thermal efficiency for flow rate of $0.005 \mathrm{~kg} / \mathrm{s}$.

Figure 5(a) - (c) show the regression line of three different tested flow rates. It was found that the efficiency of flow rate $0.005 \mathrm{~kg} / \mathrm{s}, 0.020 \mathrm{~kg} / \mathrm{s}$ and $0.030 \mathrm{~kg} / \mathrm{s}$ are $14.7 \%, 15.5 \%$ and $23.0 \%$ respectively. In addition, the thermal efficiency of the collector increased when the mass flow rate of water increased. This is because higher mass flow rate will result in higher velocity of water in the tube and will increase the temperature coefficient inside the tube.

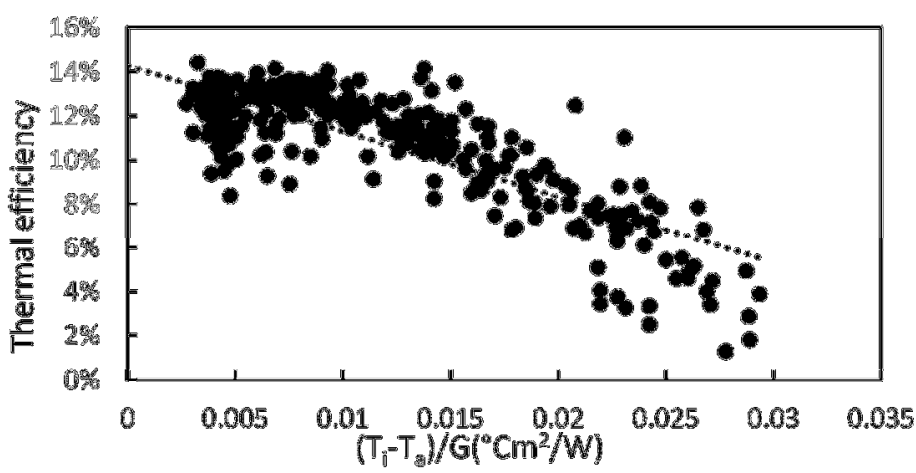

(a) 


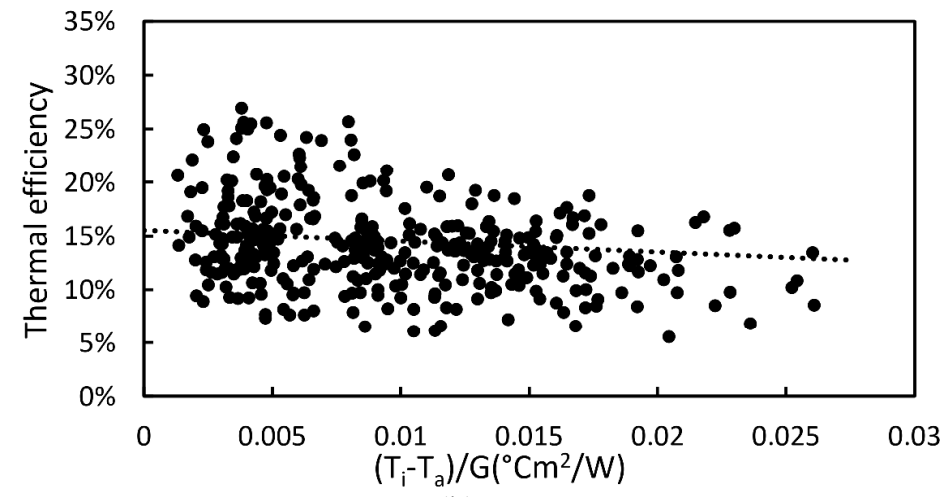

(b)

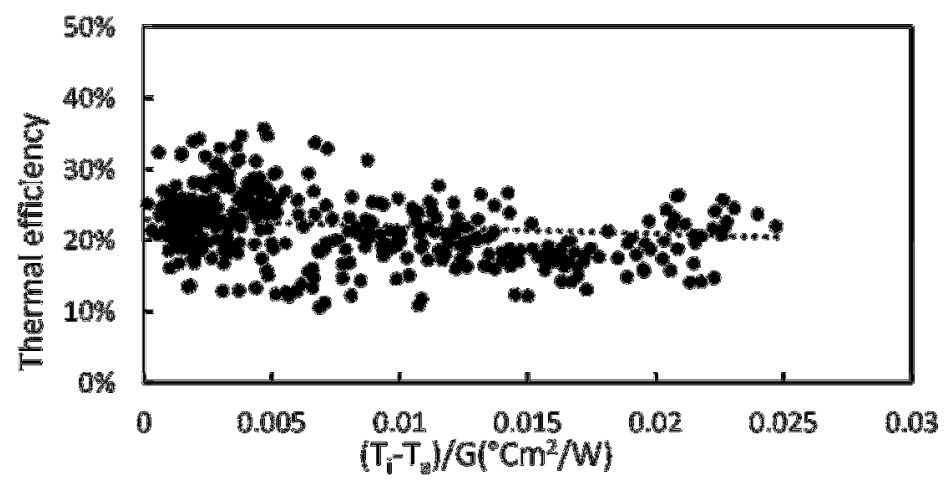

(c)

Fig. 5. Plot of thermal efficiency for mass flow rate of (a) $0.005 \mathrm{~kg} / \mathrm{s}$, (b) $0.20 \mathrm{~kg} / \mathrm{s}$, (c) $0.030 \mathrm{~kg} / \mathrm{s}$.

From the experimental results, the thermal efficiency of the tested mass flow rates can be expressed by the following regression line:

$$
\begin{aligned}
& \left.\eta_{t h}\right|_{\dot{m}=0.005 \mathrm{~kg} / \mathrm{s}}=0.147-3.116 \frac{T_{i n}-T_{a}}{G} \\
& \left.\eta_{t h}\right|_{\dot{m}=0.02 \mathrm{~kg} / \mathrm{s}}=0.155-0.999 \frac{T_{i n}-T_{a}}{G} \\
& \left.\eta_{t h}\right|_{\dot{m}=0.03 \mathrm{~kg} / \mathrm{s}}=0.230-1.0176 \frac{T_{i n}-T_{a}}{G}
\end{aligned}
$$

Figure 6 shows the relation of different PSH value with the thermal and electrical efficiency of PV/T for mass flow rate at $0.030 \mathrm{~kg} / \mathrm{s}$. Figure 6 shows PSH from 4.2 to 5.7. It was found that both electrical and thermal performance increased from PSH 4.2 to PSH 5.4 and slightly decreased when the PSH value increase to 5.7. This is because high value of PSH means the high value of solar irradiation received by the solar module which can increase the solar module temperature and decrease the PV/T performance. For the PSH 5.15, it was also found that the thermal efficiency was just slightly increase which from $18.1 \%$ to $18.3 \%$. However, the electrical efficiency shows a huge increase from $3.27 \%$ to $3.69 \%$. This is 
because the high wind speed of that day that cooled the PV temperature increased the electrical performance. On the other hand, the high wind speed reduced the total heat absorption of absorber plate and decreased the thermal efficiency.

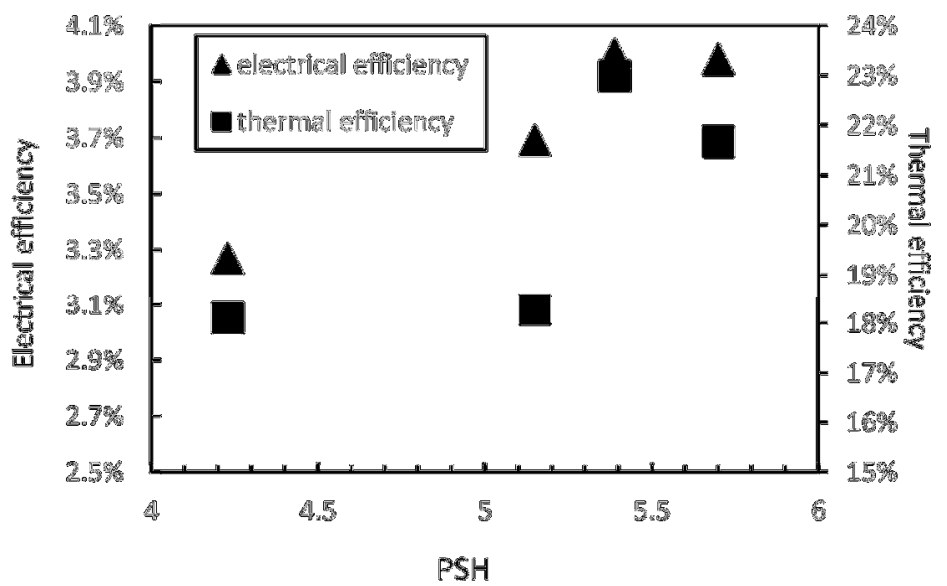

Fig. 6. PV/T performance at different PSH value for mass flow rate of $0.030 \mathrm{~kg} / \mathrm{s}$.

\section{Conclusion}

The performance of CIGS based PV/T has been tested under different mass flow rate and $\mathrm{PSH}$ value. It was found that both electrical and thermal efficiency of PV/T increase when the mass flow rate increase. However, in this study the flow rate is only limited to $0.03 \mathrm{~kg} / \mathrm{s}$ which can be further studied for higher value. For the PSH parameter, 4 values of PSH for the mass flow $0.03 \mathrm{~kg} / \mathrm{s}$ has been tested. It showed that the performance of PV/T initially increase with the PSH value from 4.2 to 5.4. When PSH value reach 5.7, both electrical and thermal performance decrease slightly. The tested value of PSH is limited to 4 value which can be further studied for more values to clarify the relation between PSH value and PV/T performance.

The author would like to acknowledge the authority of Malaysia Ministry of Education and University Malaysia Pahang upon the funding provided for the research under grant RDU140119 or FGRS/1/2014/TK06/UMP/01/1.

\section{Nomenculator}

$\begin{array}{ll}\eta & \text { efficiency (\%) } \\ I & \text { current (A) } \\ V & \text { voltage }(\mathrm{V}) \\ G & \text { solar irradiation }(\mathrm{W} / \mathrm{m} 2) \\ A & \text { area }\left(\mathrm{m}^{2}\right) \\ \dot{m} & \text { mass flow rate }(\mathrm{kg} / \mathrm{s}) \\ C_{P} & \text { specific heat }(\mathrm{J} / \mathrm{kgK}) \\ T_{\text {out }} & \text { water outlet temperature }\left({ }^{\circ} \mathrm{C}\right) \\ T_{\text {in }} & \text { water inlet temperature }\left({ }^{\circ} \mathrm{C}\right) \\ F_{R} & \text { heat removal factor of collector } \\ (\tau \alpha)_{e} & \text { effective transmittance-absorptance product } \\ U_{L} & \text { energy loss coefficient of collector }\left({ }^{\circ} \mathrm{Cm} / \mathrm{W}\right)\end{array}$




$$
\begin{array}{ll}
K_{G} & \text { coefficient of solar irradiation } \\
K_{T} & \text { coefficient of operating temperature } \\
\beta & \text { temperature coefficient of solar cell }
\end{array}
$$

\section{References}

1. R. Daghigh, M. H. Ruslan, and K. Sopian, Renew. Sustain. Energy Rev., 15 (8), pp. 4156-4170, (2011)

2. H. Zondag, Renew. Sustain. Energy Rev., 12 (4), pp. 891-959, (2008)

3. N. Aste, G. Chiesa, and F. Verri, Renew. Energy, 33 (5), pp. 914-927, (2008)

4. P. G. Charalambous, G. G. Maidment, S. A. Kalogirou, and K. Yiakoumetti, Appl. Therm. Eng., 27 (2-3), pp. 275-286, (2007)

5. A. Ibrahim, M. Y. Othman, M. H. Ruslan, M. A. Alghoul, M. Yahya, A. Zaharim, and K. Sopian, WSEAS Tr. Envir. Dev., 5 (3), pp. 321-330, (2009)

6. A. Tiwari and M. S. Sodha, Sol. Energy Mater. Sol. Cells, 91 (1), pp. 17-28, (2007)

7. S. Dubey and G. N. Tiwari, Sol. Energy, 83 (9), pp. 1485-1498, (2009)

8. T. T. Chow, Sol. Energy, 75 (2), pp. 143-152, (2003)

9. H. A. Zondag, D. W. De Vries, W. G. J. Van Helden, and R. J. C. Van Zolingen, Sol. Energy, 74, pp. 253-269, (2003)

10. T. T. Chow, W. He, and J. Ji, Sol. Energy, 80 (3), pp. 298-306, (2006)

11. A. Tiwari and M. S. Sodha, Renew. Energy, 31 (15), pp. 2460-2474, (2006)

12. A. Shahsavar and M. Ameri, Sol. Energy, 84 (11), pp. 1938-1958, (2010)

13. A. Zulkepli, L. W. Yong, M. Y. Taib, Z. Azran, and F. Basrawi, "Analysis on the Performance of Copper Indium Gallium Selenide (CIGS) Based Photovoltaic Thermal," MATEC Web Conf., 38, no. 02004, (2016)

14. X. Zhang, X. Zhao, S. Smith, J. Xu, and X. Yu, Renew. Sustain. Energy Rev., 16 (1), pp. 599-617, (2012) 